\title{
Present and Future of Endoscopic Ultrasound-Guided Tissue Acquisition in Solid Pancreatic Tumors
}

\author{
Jae Keun Park ${ }^{1}$ and Kwang Hyuck Lee ${ }^{2}$ \\ ${ }^{1}$ Digestive Disease Center and Research Institute, Department of Internal Medicine, Soon Chun Hyang University School of Medicine, \\ Bucheon, ${ }^{2}$ Department of Medicine, Samsung Medical Center, Sungkyunkwan University School of Medicine, Seoul, Korea
}

Endoscopic ultrasound-guided tissue acquisition (EUS-TA) is a well-established method for pathological diagnosis of solid pancreatic neoplasm. It can be performed either as EUS-guided fine-needle aspiration (EUS-FNA) or EUS-guided fine-needle biopsy (EUSFNB). The incidence of adverse events related to EUS-TA is less than 1\%. The factors that affect the diagnostic accuracy and specimen adequacy include the techniques used, type and size of the needle, competency of endosonographers, presence of cytopathologists/ cytotechnologists, and rapid on-site examination. EUS-TA may contribute to precision medicine through obtaining tissue samples for next-generation sequencing. The current status, several clinical issues for diagnostic yield and adverse events, and future perspectives of EUS-FNA/FNB for diagnosing pancreatic neoplasm have been discussed in this review article. Clin Endosc 2019;52:541-548

Key Words: Endoscopic ultrasound; Endoscopic ultrasound-guided fine-needle aspiration; Fine-needle biopsy; Pancreatic neoplasm

\section{INTRODUCTION}

Endoscopic ultrasound-guided tissue acquisition (EUSTA) is a well-established method for tissue diagnosis of solid pancreatic neoplasm. ${ }^{1-3}$ Currently, EUS-guided fine-needle aspiration (EUS-FNA) is the standard diagnostic tool for the accurate diagnosis of pancreatic neoplasm. ${ }^{4-6}$ The final results of EUS-FNA vary in terms of sensitivity (64\%-95\%), specificity (75\%-100\%), and diagnostic accuracy (78\%-95\%). 4,78 However, EUS-FNA has limitations. It often provides only a cytological sample for diagnosis. In some pancreatic neoplasms, such as stromal tumors and lymphomas, histological specimens are required. ${ }^{9}$ Further, the diagnostic accuracy of EUS-FNA can be affected by the presence of a rapid on-site cytopathology

Received: June 26, 2019 Revised: October 26, 2019

Accepted: November 3, 2019

Correspondence: Kwang Hyuck Lee

Department of Medicine, Samsung Medical Center, Sungkyunkwan University School of Medicine, 81 Irwon-ro, Gangnam-gu, Seoul 06351, Korea

Tel: +82-2-3410-3409, Fax: +82-2-3410-6983, E-mail: 1khyuck@gmail.com ORCID: https://orcid.org/0000-0002-5558-0415

(c) This is an Open Access article distributed under the terms of the Creative Commons Attribution Non-Commercial License (http://creativecommons.org/ licenses/by-nc/3.0) which permits unrestricted non-commercial use, distribution, and reproduction in any medium, provided the original work is properly cited. evaluation (ROSE); in some centers, ROSE is not available. ${ }^{10}$

To overcome these limitations, newly designed needles for core biopsy, i.e., EUS-guided fine-needle biopsy (EUS-FNB), were developed. Initially, $19 \mathrm{G}$ needles, which had a firing system, were developed. The diagnostic accuracy of these $19 \mathrm{G}$ needles was $89.4 \%$ in a previous study involving 47 cases of pancreatic neoplasm. ${ }^{11}$

Because of the technical difficulty in the use of $19 \mathrm{G}$ needles for transduodenal procedures, novel needle sizes of $22 \mathrm{G}$ and $25 \mathrm{G}$ were developed. This article focuses on (1) addressing the current role of EUS-FNA/FNB in pancreatic neoplasm, (2) comparing EUS-FNA with EUS-FNB, (3) exploring the variables that impact diagnostic accuracy and specimen adequacy, (4) evaluating the adverse events of EUS-FNA/FNB, and (5) determining the future of EUS-FNA/FNB for precision medicine.

\section{DEVELOPMENT OF NEEDLES FOR EUS- TA}

EUS-TA for solid lesions in the pancreas is the test of choice for nonoperative pathological diagnosis. ${ }^{12-15}$ Moreover, in cases 
of negative or indeterminate diagnoses based on EUS-guided tissue sampling findings in the presence of suspected pancreatic malignancy, recent guidelines recommend either performing revision on the initial pathology specimens obtained or repeating EUS-TA. For pancreatic cystic lesions with worrisome features, including clinical symptoms of pancreatitis, cysts measuring more than $3 \mathrm{~cm}$, enhancing mural nodules measuring less than $5 \mathrm{~mm}$, thickened/enhancing cyst walls, main duct size of 5-9 mm, abrupt change in the caliber of the pancreatic duct with distal pancreatic atrophy, lymphadenopathy, increased serum CA19-9 level, and cyst growth rate of more than $5 \mathrm{~mm}$ every 2 years, the European Society of Gastrointestinal Endoscopy (ESGE) recommended EUS-TA for biochemical and cytological evaluations. At first, only EUSFNA needles measuring either 19 or 22 to $25 \mathrm{G}$ were available for tissue acquisition. ${ }^{13}$ EUS-FNB needles were introduced thereafter owing to the limitations of EUS-FNA needles.

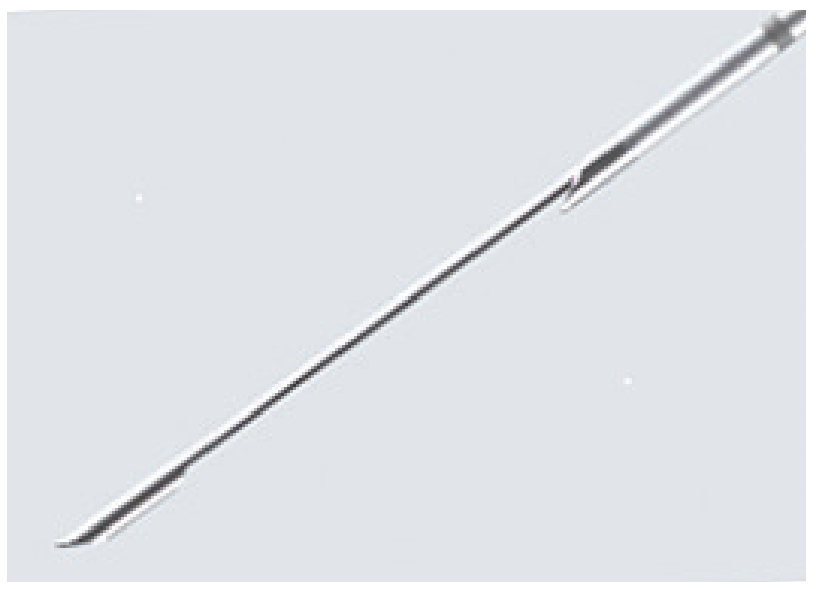

Fig. 1. Tip of a trucut fine-needle biopsy needle (QuickCore ${ }^{\circledR}$ needle; Cook Medical, Inc., Winston-Salem, NC, USA).

\section{CURRENTLY AVAILABLE NEEDLES FOR EUS-TA}

Trucut biopsy needles (QuickCore ${ }^{\circledR}$ needle; Cook Medical, Inc., Winston-Salem, NC, USA) were initially used as EUSFNB needles (Fig. 1). However, the size of the trucut biopsy needle available for EUS-FNB was 19 G, which was relatively stiff. Thus, there was considerable resistance in the firing of the cutting sheath for tissue cutting. Currently, the following three EUS-FNB needles are available for clinical use: (1) Procore $^{\circledR}$ needle (Cook Medical, Inc.) with a cutting bevel (reverse for 19,22 , and $25 \mathrm{G}$ and $20 \mathrm{G}$ antegrade beveled side slot) at the needle tip (Fig. 2A), (2) Acquire ${ }^{\mathrm{TM}}$ end-cutting needle (Boston Scientific Co., Marlborough, MA, USA) with a threepoint needle tip (22 and 25 G) (Fig. 2B), and (3) SharkCore ${ }^{\mathrm{TM}}$ needle (Medtronic, Minneapolis, MN, USA) with six distal cutting edges at the needle tip $\left(19,22\right.$, and $25 \mathrm{G}$ ) (Fig. 2C). ${ }^{16}$ However, higher rates of adverse events and technical failure are noted with the use of large needles. Furthermore, smaller needle sizes, such as 22 and 25 G, are more technically feasible. ${ }^{16-18}$ In general, more tissue will be obtained for histological assessment with larger needle sizes.

\section{DIAGNOSTIC YIELD OF EUS-TA: EUS- FNA VS. EUS-FNB}

According to the characteristics of the pancreatic lesion, the diagnostic yields are somewhat different. In cases of pancreatic cancers, only cytology is enough for diagnosis; however, histology and immunohistochemical staining are required for the nonmalignant pancreatic mass. ${ }^{19}$ In this aspect, a larger needle (19 G) is preferred in lesions requiring tissue architectural and immunohistochemical stains for diagnosis, such as metastatic pancreatic neoplasm and lymphoma. In previous studies, the reported cytological diagnostic accuracies were 89.7\%-90\% (EUS-FNA) and 93.1\%-93.3\% (EUS-FNB) in solid
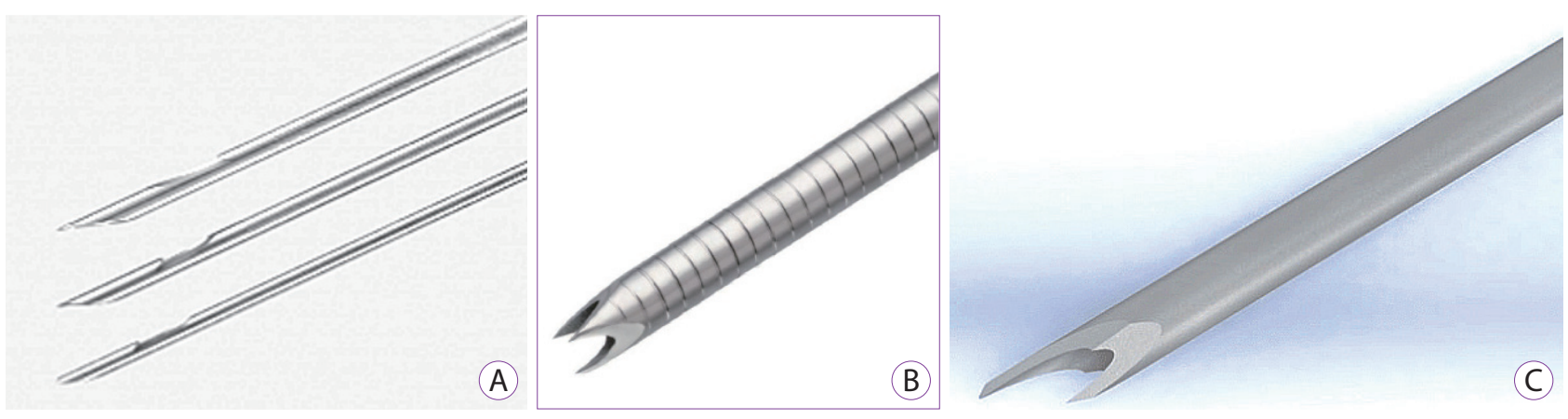

Fig. 2. Tips of three different endoscopic ultrasound-guided fine-needle biopsy needles: (A) Procore ${ }^{\circledR}$ needles; Cook Medical, Inc., Winston-Salem, NC, USA). (B) Acquire $^{\mathrm{TM}}$ end-cutting needle (Boston Scientific Co., Marlborough, MA, USA). (C) SharkCore ${ }^{\mathrm{TM}}$ needle (Medtronic, Minneapolis, MN, USA). 
pancreatic neoplasm. Moreover, the histological diagnostic accuracies were relatively lower than the cytological diagnostic accuracies, i.e., $77.6 \%-80 \%$ vs. $71.7 \%-82.8 \%(p=0.642)$ for EUS-FNA and EUS-FNB needles in solid pancreatic neoplasm, respectively. ${ }^{18,20}$ Several crossover comparative studies investigated both needles. Vanbiervliet et al. reported that the overall diagnostic accuracy was not different between EUS-FNA and EUS-FNB needles (92.5\% vs. $90 \%$, respectively, $p=0.68){ }^{21}$ According to the most recently conducted randomized controlled trial, EUS-FNA and EUS-FNB had a diagnostic accuracy of $84 \%$ and $90 \%$, respectively $(p=0.8){ }^{22}$ In this study, EUS-FNB demonstrated higher histological quality than EUS-FNA. The results of previous randomized controlled trials are summarized in Table $1 .{ }^{20-27}$ In their previous meta-analysis, Wang et al. demonstrated that EUSFNB is comparable to EUS-FNA in terms of the diagnostic accuracy, adverse events, and technical success. ${ }^{28}$ Currently, the ESGE guideline recommends both 25 and $22 \mathrm{G}$ needles for sampling pancreatic solid masses regardless of the needle type. ${ }^{29}$ However, a fewer number of needle passes are needed for obtaining sufficient tissue and achieving higher specimen adequacy in EUS-FNB than in EUS-FNA (Table 1). ${ }^{30,31}$ In cases of metastatic pancreatic neoplasm and lymphoma, the ESGE guideline recommends the use of a large-bore FNB needle $(19$ or $22 \mathrm{G})$ for complete tissue architecture. ${ }^{12}$

\section{DETERMINING FACTORS OF DIAGNOSTIC ACCURACY AND SPECIMEN ADEQUACY}

Several variables can affect the results, including (1) the procedure technique, (2) needle type and size, (3) competency of endosonographers, and (4) presence of cytopathologists or

Table 1. Comparison of Endoscopic Ultrasound-Guided Fine-Needle Aspiration and Endoscopic Ultrasound-Guided Fine-Needle Biopsy of the Previous Randomized Controlled Trials

\begin{tabular}{|c|c|c|c|c|c|c|c|c|}
\hline Study & $\begin{array}{c}\text { Patients } \\
\text { (FNA : FNB) }\end{array}$ & $\begin{array}{l}\text { Needles size } \\
\text { (G) }\end{array}$ & $\begin{array}{c}\text { Needle } \\
\text { manufacturer }\end{array}$ & $\begin{array}{c}\text { Diagnostic } \\
\text { accuracy } \\
\text { (odds ratio, } \\
95 \% \mathrm{CI} \text { ) }\end{array}$ & $\begin{array}{c}\text { Specimen } \\
\text { adequacy } \\
\text { (odds ratio, } \\
95 \% \mathrm{CI} \text { ) }\end{array}$ & $\begin{array}{c}\text { Number of } \\
\text { needle pass } \\
\text { (mean } \\
\text { difference, } \\
95 \% \mathrm{CI})\end{array}$ & $\begin{array}{c}\text { Adverse } \\
\text { events } \\
\text { (odds ratio, } \\
95 \% \mathrm{CI} \text { ) }\end{array}$ & $\begin{array}{c}\text { Technical } \\
\text { success } \\
\text { (odds ratio, } \\
\text { 95\% CI) }\end{array}$ \\
\hline $\begin{array}{l}\text { Lee et al. } \\
(2014)^{20}\end{array}$ & $58: 58$ & $\begin{array}{l}22 \text { G FNA } 30 \\
25 \text { G FNA } 28 \\
22 \text { G FNB } 34 \\
25 \text { G FNB } 24\end{array}$ & Cook Medical & $\begin{array}{c}0.32 \\
(0.03-3.19)\end{array}$ & - & - & $\begin{array}{c}0.32 \\
(0.03-3.19)\end{array}$ & - \\
\hline $\begin{array}{l}\text { Vanbiervliet et } \\
\text { al. }(2014)^{21}\end{array}$ & $80: 80$ & $\begin{array}{l}22 \text { G FNA } 80 \\
22 \text { G FNB } 80\end{array}$ & Cook Medical & $\begin{array}{c}1.37 \\
(1.45-4.15)\end{array}$ & $\begin{array}{c}1.90 \\
(0.61-5.95)\end{array}$ & - & - & - \\
\hline $\begin{array}{l}\text { Strand et al. } \\
(2014)^{22}\end{array}$ & $32: 32$ & $\begin{array}{l}22 \text { G FNA } 32 \\
22 \text { G FNB } 32\end{array}$ & Cook Medical & - & - & $\begin{array}{c}1.50 \\
(0.91-2.09)\end{array}$ & - & $\begin{array}{c}13.00 \\
(0.69-245.72)\end{array}$ \\
\hline $\begin{array}{l}\text { Bang et al. } \\
(2012)^{23}\end{array}$ & $28: 28$ & $\begin{array}{l}22 \text { G FNA } 28 \\
22 \text { G FNB } 28\end{array}$ & $\begin{array}{c}\text { Boston } \\
\text { Scientific } \\
\text { Cook Medical }\end{array}$ & $\begin{array}{c}7.82 \\
(0.39-158.87)\end{array}$ & - & $\begin{array}{c}0.33 \\
(-0.05-0.71)\end{array}$ & $\begin{array}{c}1.00 \\
(0.06-16.82)\end{array}$ & $\begin{array}{c}3.11 \\
(0.12-79.64)\end{array}$ \\
\hline $\begin{array}{l}\text { Hucl et al. } \\
\qquad(2013)^{24}\end{array}$ & $69: 69$ & $\begin{array}{l}22 \text { G FNA } 69 \\
22 \text { G FNB } 69\end{array}$ & Cook Medical & $\begin{array}{c}0.48 \\
(0.20-1.13)\end{array}$ & $\begin{array}{c}0.52 \\
(0.17-1.64)\end{array}$ & $\begin{array}{c}1.04 \\
(0.78-1.30)\end{array}$ & - & - \\
\hline $\begin{array}{l}\text { Aadam et al. } \\
(2016)^{25}\end{array}$ & $70: 70$ & $\begin{array}{c}19 \text { G FNA } 0 \\
19 \text { G FNB } 7 \\
22 \text { G FNA } 48 \\
22 \text { G FNB } 37 \\
25 \text { G FNA } 22 \\
25 \text { G FNB } 26\end{array}$ & Cook Medical & $\begin{array}{c}0.33 \\
(0.08-1.36)\end{array}$ & $\begin{array}{c}0.42 \\
(0.14-1.27)\end{array}$ & - & - & - \\
\hline $\begin{array}{l}\text { Kamata et al. } \\
(2016)^{26}\end{array}$ & $108: 106$ & $\begin{array}{l}25 \text { G FNA } 108 \\
25 \text { G FNB } 106\end{array}$ & Cook Medical & $\begin{array}{c}0.83 \\
(0.43-1.57)\end{array}$ & $\begin{array}{c}0.53 \\
(0.28-1.00)\end{array}$ & - & - & - \\
\hline $\begin{array}{c}\text { Alatawi et al. } \\
(2015)^{27}\end{array}$ & $50: 50$ & $\begin{array}{l}22 \text { G FNA } 50 \\
22 \text { G FNB } 50\end{array}$ & Cook Medical & $\begin{array}{c}0.58 \\
(0.18-1.92)\end{array}$ & $\begin{array}{c}0.08 \\
(0.00-1.52)\end{array}$ & $\begin{array}{c}0.69 \\
(0.38-1.00)\end{array}$ & - & - \\
\hline Total & - & - & - & $\begin{array}{c}0.72 \\
(0.49-1.07)\end{array}$ & $\begin{array}{c}0.57 \\
(0.37-0.89)\end{array}$ & $\begin{array}{c}0.86 \\
(0.45-1.26)\end{array}$ & $\begin{array}{c}0.49 \\
(0.09-2.74)\end{array}$ & $\begin{array}{c}7.74 \\
(0.94-64.00)\end{array}$ \\
\hline
\end{tabular}

CI, confidence interval; FNA, fine-needle aspiration; FNB, fine-needle biopsy. 
cytotechnologists.

\section{Technique}

Application of suction during EUS-TA is dependent on the quality of the first sample. In case the first pass has a large amount of blood contamination based on ROSE or gross examination findings, no suction aspiration should be performed in the next pass. Similarly, an insufficient tissue amount of the first puncture without suction requires application of suction in the next puncture. Tailored use of capillary (slow pull-back of stylet during needle passes) or suction according to the characteristics of target pancreatic lesion and/ or ROSE or gross examination of specimen may increase the diagnostic yield. A previous randomized controlled trial has compared the diagnostic yield and cytological characteristics of EUS-FNA samples with and without the suction technique in patients with pancreatic neoplasm. ${ }^{1}$ EUS-FNA samples in which the suction technique was used showed higher diagnostic yield, accuracy, bloodiness, and cellularity than did those in which the technique was not used. This might be because most target lesions were pancreatic cancers. In cases of EUS-FNA samples of lymph nodes, EUS-FNA with suction increases bloodiness without impacting the diagnostic yield. ${ }^{32}$ The usefulness of capillary, wet suction, and suction with high negative pressure techniques need to be validated according to different pancreatic lesions. ${ }^{25,33,34}$

The most recently conducted randomized controlled trial reported that the "fanning" motion of needles was superior to sampling in a single lesion per pass. ${ }^{35}$ It may affect multiple regions in the pancreatic lesion during each pass of the needle. Several previous randomized controlled trials have demonstrated that there was no difference between groups of patients undergoing EUS-TA with and without the use of a stylet. Thus, the use of a stylet during EUS-TA cannot be recommended. ${ }^{36-38}$ Instead, air flushing by gently pushing seems to be superior to EUS-TA with the use of a stylet according to a recent randomized controlled trial. Further, another recent randomized controlled trial reported that at least six needle passes for lesions measuring less than or equal to $2 \mathrm{~cm}$ and four needle passes for lesions measuring greater than $2 \mathrm{~cm}$ should be performed to optimize the sensitivity in pancreatic neoplasms without ROSE. ${ }^{24}$ Most experts think that proper puncturing during EUS-TA is important to improve the diagnostic yield in addition to obtaining adequate gross samples and arriving to the expected diagnosis of a lesion based on pretest examination findings.

\section{Needle type and size}

A recent meta-analysis reported that there is no significant difference in the diagnostic accuracy and sample adequacy for pathological and histological examinations between EUS-FNA and EUS-FNB needles. However, a fewer number of needle passes were required to achieve diagnosis in EUS-FNB. ${ }^{28}$ Although 22 or 25 G EUS-FNA needles are routinely used in pancreatic solid lesions and lymph nodes, a meta-analysis reported a higher sensitivity with the use of a $25 \mathrm{G}$ needle than with that of a $22 \mathrm{G}$ needle (pooled sensitivity, 0.93 [95\% confidence interval, $0.91-0.96$ ] vs. 0.85 [ $95 \%$ confidence interval, 0.82-0.88]) during EUS-FNA of pancreatic neoplasms. ${ }^{4}$ In the comparisons between 22 and $25 \mathrm{G}$ core biopsy needles in EUS-FNB, no significant difference in diagnostic performance has been reported. ${ }^{39}$

\section{Competency/experience of endosonographers}

The American Society for Gastrointestinal Endoscopy recommended 150 supervised EUS procedures before competency. ${ }^{40}$ Current guidelines recommend a minimum of 225 procedures (most for pancreatic biliary indications) before competency can be determined. ${ }^{41}$ However, this is further complicated by other societies because of limited data and reliance on expert opinions. Current studies reported that advanced endoscopy trainees had different rates of learning curves in EUS, and specific cases in EUS were not related to competency. ${ }^{42-44}$ Interestingly, in most advanced procedures, the volumes of operators and centers are closely related to each other. However, in EUS, they do not seem to be closely related.

\section{Presence of cytopathologists/cytotechnologists and ROSE}

Real-time feedback of EUS-TA (EUS-FNA/FNB) specimens by cytopathologists and cytotechnologists can not only make an accurate diagnosis but also increase efficiency with fewer numbers of needle passes during the procedure. However, a previous randomized controlled trial reported that there is no significant difference in the rates of inadequate specimens obtained and diagnostic yield of malignancy. ${ }^{45}$ This study compared between EUS-FNA specimens with and without ROSE. Further, several studies demonstrated that there was no significant difference in the diagnostic yield during EUS$\mathrm{FNB}^{25,46,47}$

Nevertheless, ROSE may have a crucial role for less experienced endosonographers and medical centers with low tissue specimen adequacy. ${ }^{48}$ Moreover, appropriate selection for additional tests (molecular analysis, flow cytometry, immunohistochemistry, and cytogenetics) with limitations of specimens can be possible with ROSE by cytopathologists and cytotechnologists. ${ }^{49,50}$ The role of ROSE will continue to increase because of technical improvements in EUS-TA, including the newer EUS-FNB. 


\section{ADVERSE EVENTS RELATED TO EUS-TA}

The incidence of adverse events in EUS-TA (EUS-FNA/ FNB) was relatively low in a previous comprehensive nationwide retrospective study. ${ }^{51}$ Infection and pancreatitis were the most common adverse events. In the study, clinically severe adverse events occurred only in $0.29 \%$ of all EUS-TA cases without any mortality. This result is consistent with that of the survey on severe adverse event rates in Japan $(0.23 \%){ }^{52}$ The adverse event rate for EUS-FNA is less than $1 \%{ }^{53}$ Yang et al. reported that EUS-FNB had a comparable adverse event rate with EUS-FNA. ${ }^{54}$ The diagnostic accuracy and specimen adequacy in previous clinical studies are described in Table $1 .^{20,23,24,26}$ The recent meta-analysis conducted by Wang et al. reported that only one study found adverse events after surgery, including acute pancreatitis, abdominal pain, bleeding, and gastric hematoma, and all patients recovered rapidly after conservative treatment. ${ }^{28}$ The pooled analysis showed that the rate of adverse events did not significantly differ between their two groups.

\section{FUTURE PROSPECT OF EUS-TA}

With the recent developments in human genomics and sequencing technology, personalized medicine of cancer has become a reality. ${ }^{55}$ Next-generation sequencing (NGS) has been widely implemented for gene sequencing (Fig. 3). ${ }^{56}$ Recently, several studies have revealed the mutational landscape of pancreatic cancer using NGS. For genomic analyses, formalin-fixed and paraffin-embedded specimens have been preferred. Thus, it was believed that EUS-FNB may be necessary and superior for obtaining adequate tumor tissue for NGS. However, several studies reported that the

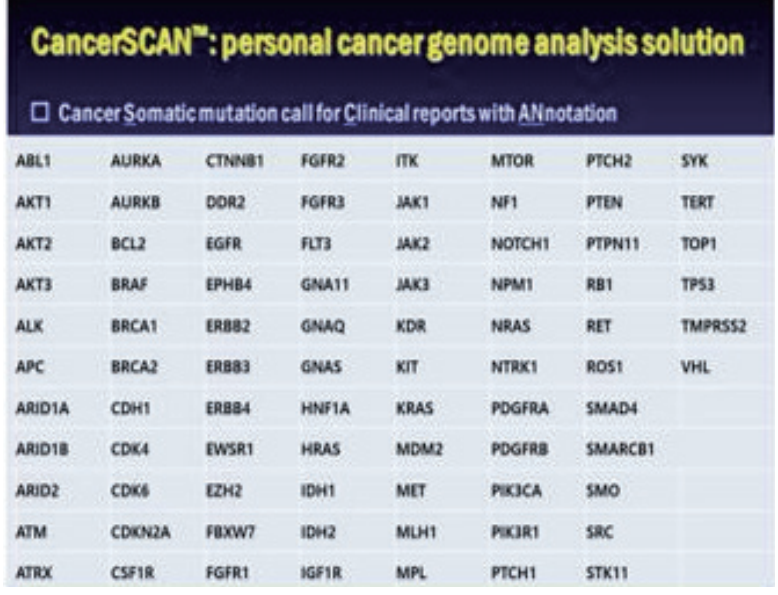

(A)

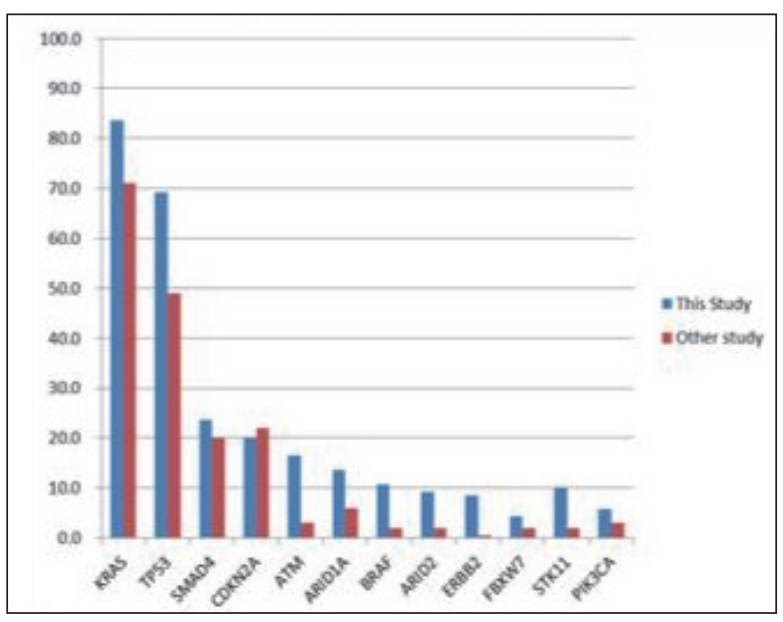

(C)
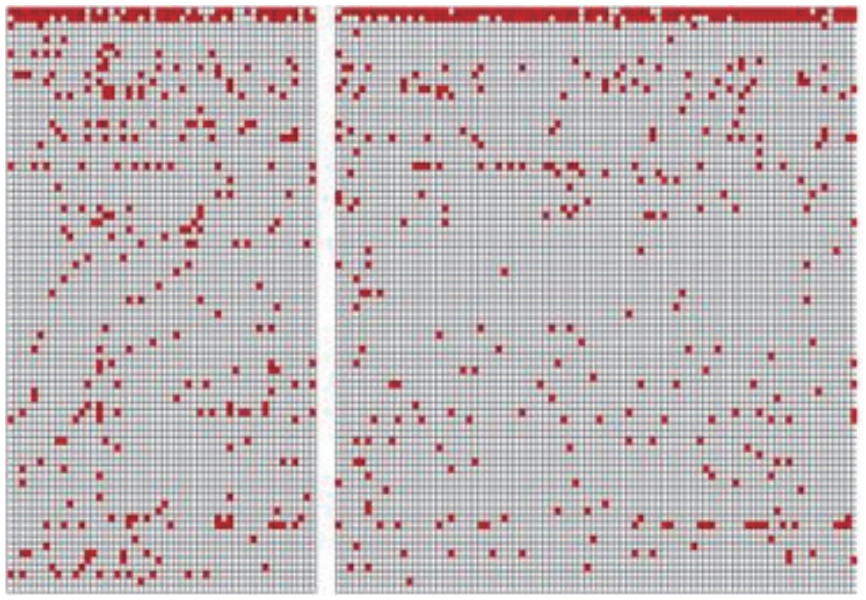

(B)

\begin{tabular}{|c|c|c|c|c|}
\hline & $\begin{array}{l}\text { Long-term } \\
\text { survival }\end{array}$ & $\begin{array}{c}\text { Intermediate } \\
\text { survival }\end{array}$ & $\begin{array}{c}\text { Short-term } \\
\text { survival }\end{array}$ & p value \\
\hline KRAS mutation, $\mathrm{n}(\%)$ & & & & 0.017 \\
\hline No & $3(27)$ & $16(16)$ & $4(13)$ & \\
\hline Mutation & $8(73)$ & $83(84)$ & $26(86.7)$ & \\
\hline AL.K mutation, $n(\%)$ & & & & 0.023 \\
\hline No & $9(82)$ & $93(94)$ & $29(97)$ & \\
\hline Mutation & $2(18)$ & $6(6)$ & $1(3)$ & \\
\hline CSF1R mutation, $n(\%)$ & & & & 0.003 \\
\hline No & $10(91)$ & $97(98)$ & $28(93)$ & \\
\hline Mutation & $1(9)$ & $2(2)$ & $2(7)$ & \\
\hline ITK mutation, $n(\%)$ & & & & 0.008 \\
\hline No & $10(91)$ & $98(99)$ & $29(97)$ & \\
\hline Mutation & $1(9)$ & $1(1)$ & $1(3)$ & \\
\hline NF1 mutation, $\mathrm{n}(\%)$ & & & & 0.023 \\
\hline No & $10(91)$ & $89(90)$ & $24(80)$ & \\
\hline Mutation & $1(9)$ & $10(10)$ & $6(20)$ & \\
\hline RB1 mutation, n (\%) & & & & 0.001 \\
\hline No & $10(91)$ & $98(99)$ & $29(97)$ & \\
\hline Mutation & $1(9)$ & $1(1)$ & $1(3)$ & \\
\hline
\end{tabular}

(D)

Fig. 3. Next-generation sequencing with key mutation gene: (A) Gene list of the panel. (B) Gene mutation frequencies. (C) Frequency of major genes in pancreatic cancer. (D) Genetic alterations associated with survivial after univariate analysis. 
cytological samples obtained in EUS-FNA are superior to the histological samples obtained in EUS-FNB. One previous study has demonstrated that the cytological samples in EUSFNA confer a high concentration of pure tumor cells compared with the histological samples in EUS-FNB. ${ }^{57}$ Furthermore, alcohol-based fixation for cytological samples preserves nucleic acid for genomic analyses. ${ }^{58}$ Cytological samples also have intact cells compared with histological specimens owing to the sectioning procedure for the latter. However, the relatively low proportion of adequate materials for NGS in EUSFNA remains a problem. Only $12.4 \%$ of materials for NGS in EUS-FNA were obtained from malignant pancreatic masses. ${ }^{59}$ Nevertheless, a recent report concurrently assessing FNA and core needle biopsies found that EUS-FNA may be sufficient for NGS owing to better cellularity and NGS metrics and higher tumor fractions compared with EUS-FNB. ${ }^{60}$ Thus, it is uncertain whether EUS-FNB is more superior to EUS-FNA in regard to tissue acquisition for NGS. Multicenter prospective studies are required to elucidate the role of EUS-TA and factors for successful EUS-TA sampling in any type of tissues for diagnostic and theranostic purposes.

Several studies demonstrated that new methods, such as cytological sampling using smears, ThinPrep slides, and cell blocks, are available for genomic analysis. Among these methods, liquid cytological sampling (FNA rinse material) is excellent and often superior for personalized medicine. ${ }^{61,62}$ Further, RNA and microRNA sequencing, ${ }^{63-66}$ fluorescence in situ hybridization, ${ }^{67}$ use of protein and immune markers and tumor organoids, ${ }^{68-71}$ and low-cost whole-exome sequencing are currently the emerging fields in EUS-TA. Successful NGS from single circulating tumor cells was also reported. ${ }^{72,73}$ By using circulating tumor cells, sampling is completely different from previous methods, such as sampling from peripheral blood $^{74}$ or EUS-guided portal vein sampling. ${ }^{75}$ However, there are limited reports on these new emerging methods. Future studies need to determine whether EUS-FNB is superior to EUS-FNA in combination with the new emerging methods.

\section{CONCLUSIONS}

First, this article summarized the current knowledge regarding the role of EUS-TA, comparing between EUS-FNA and EUS-FNB. Second, this article documented the outcomes, variables, and adverse events of EUS-TA for routine clinical practice. Third, this article explored the prospect of EUS-TA for pancreatic masses for personalized medicine. Currently, EUS-TA clearly plays a vital role in oncological care. Although the comparison between EUS-FNA and EUS-FNB for the diagnosis of pancreatic neoplasm is still controversial, several previous randomized clinical trials have reported that EUSFNB is comparable to EUS-FNA in terms of the diagnostic accuracy, adverse events, and technical success. Meanwhile, EUS-FNB requires a fewer number of needle passes to obtain sufficient tissue and higher specimen adequacy. Further, both EUS-FNA and FNB are very safe. Although EUSTAs were performed in many pancreatic cancer cases, EUSTA methods are not standardized due to multiple variables. As we have mentioned, complex processes with different variables, including sampling techniques, are closely related to improvement of the final results of EUS-TA for the diagnosis of pancreatic neoplasm. Thus, it is important to approach EUS-TA in a multidisciplinary manner not only for diagnostics but also for theranostics. EUS-TA currently has an important role in the upcoming era of personalized medicine. However, future higher-grade multicenter prospective studies are needed to optimize EUS-TA for theranostic purposes.

Conflicts of Interest

The authors have no financial conflicts of interest.

ORCID

Jae Keun Park: https://orcid.org/0000-0002-8323-9660

\section{REFERENCES}

1. Lee JK, Choi JH, Lee $\mathrm{KH}$, et al. A prospective, comparative trial to optimize sampling techniques in EUS-guided FNA of solid pancreatic masses. Gastrointest Endosc 2013;77:745-751.

2. Lee JK, Lee KT, Choi ER, et al. A prospective, randomized trial comparing 25-gauge and 22-gauge needles for endoscopic ultrasound-guided fine needle aspiration of pancreatic masses. Scand J Gastroenterol 2013;48:752-757.

3. Dumonceau JM, Polkowski M, Larghi A, et al. Indications, results, and clinical impact of endoscopic ultrasound (EUS)-guided sampling in gastroenterology: European Society of Gastrointestinal Endoscopy (ESGE) clinical guideline. Endoscopy 2011;43:897-912.

4. Yoshinaga S, Suzuki H, Oda I, Saito Y. Role of endoscopic ultrasound-guided fine needle aspiration (EUS-FNA) for diagnosis of solid pancreatic masses. Dig Endosc 2011;23 Suppl 1:29-33.

5. Iglesias-Garcia J, Lariño-Noia J, Abdulkader I, Domínguez-Muñoz JE. Rapid on-site evaluation of endoscopic-ultrasound-guided fine-needle aspiration diagnosis of pancreatic masses. World J Gastroenterol 2014;20:9451-9457.

6. Fritscher-Ravens A, Topalidis T, Bobrowski C, et al. Endoscopic ultrasound-guided fine-needle aspiration in focal pancreatic lesions: a prospective intraindividual comparison of two needle assemblies. Endoscopy 2001;33:484-490.

7. Itoi T, Sofuni A, Itokawa F, Irisawa A, Khor CJ, Rerknimitr R. Current status of diagnostic endoscopic ultrasonography in the evaluation of pancreatic mass lesions. Dig Endosc 2011;23 Suppl 1:17-21.

8. Eloubeidi MA, Chen VK, Eltoum IA, et al. Endoscopic ultrasound-guided fine needle aspiration biopsy of patients with suspected pancreatic cancer: diagnostic accuracy and acute and 30-day complications. Am J Gastroenterol 2003;98:2663-2668.

9. Levy MJ, Wiersema MJ. EUS-guided Trucut biopsy. Gastrointest Endosc 
2005;62:417-426

10. Iglesias-Garcia J, Dominguez-Munoz JE, Abdulkader I, et al. Influence of on-site cytopathology evaluation on the diagnostic accuracy of endoscopic ultrasound-guided fine needle aspiration (EUS-FNA) of solid pancreatic masses. Am J Gastroenterol 2011;106:1705-1710.

11. Iglesias-Garcia J, Poley JW, Larghi A, et al. Feasibility and yield of a new EUS histology needle: results from a multicenter, pooled, cohort study. Gastrointest Endosc 2011;73:1189-1196.

12. Dumonceau JM, Deprez PH, Jenssen C, et al. Indications, results, and clinical impact of endoscopic ultrasound (EUS)-guided sampling in gastroenterology: European Society of Gastrointestinal Endoscopy (ESGE) clinical guideline - updated January 2017. Endoscopy 2017;49:695-714.

13. Elta GH, Enestvedt BK, Sauer BG, Lennon AM. ACG clinical guideline: diagnosis and management of pancreatic cysts. Am J Gastroenterol 2018;113:464-479.

14. ASGE Standards of Practice Committee, Muthusamy VR, Chandrasekhara $\mathrm{V}$, et al. The role of endoscopy in the diagnosis and treatment of cystic pancreatic neoplasms. Gastrointest Endosc 2016;84:1-9.

15. Tanaka M, Fernández-Del Castillo C, Kamisawa T, et al. Revisions of international consensus Fukuoka guidelines for the management of IPMN of the pancreas. Pancreatology 2017;17:738-753.

16. Ang TL, Kwek ABE, Wang LM. Diagnostic endoscopic ultrasound: technique, current status and future directions. Gut Liver 2018;12:483496.

17. Ayres LR, Kmiotek EK, Lam E, Telford JJ. A comparison of endoscopic ultrasound-guided fine-needle aspiration and fine-needle biopsy in the diagnosis of solid pancreatic lesions. Can J Gastroenterol Hepatol 2018;2018:1415062.

18. Noh DH, Choi K, Gu S, et al. Comparison of 22-gauge standard fine needle versus core biopsy needle for endoscopic ultrasound-guided sampling of suspected pancreatic cancer: a randomized crossover trial. Scand J Gastroenterol 2018;53:94-99.

19. Park JK, Kang KJ, Oh CR, et al. Evaluating the minimal specimens from endoscopic ultrasound-guided fine-needle aspiration in pancreatic masses. Medicine (Baltimore) 2016;95:e3740.

20. Lee YN, Moon JH, Kim HK, et al. Core biopsy needle versus standard aspiration needle for endoscopic ultrasound-guided sampling of solid pancreatic masses: a randomized parallel-group study. Endoscopy 2014;46:1056-1062

21. Vanbiervliet G, Napoléon B, Saint Paul MC, et al. Core needle versus standard needle for endoscopic ultrasound-guided biopsy of solid pancreatic masses: a randomized crossover study. Endoscopy 2014;46:10631070.

22. Strand DS, Jeffus SK, Sauer BG, Wang AY, Stelow EB, Shami VM. EUS-guided 22-gauge fine-needle aspiration versus core biopsy needle in the evaluation of solid pancreatic neoplasms. Diagn Cytopathol 2014;42:751-758.

23. Bang JY, Hebert-Magee S, Trevino J, Ramesh J, Varadarajulu S. Randomized trial comparing the 22-gauge aspiration and 22-gauge biopsy needles for EUS-guided sampling of solid pancreatic mass lesions. Gastrointest Endosc 2012;76:321-327.

24. Hucl T, Wee E, Anuradha S, et al. Feasibility and efficiency of a new $22 \mathrm{G}$ core needle: a prospective comparison study. Endoscopy 2013;45:792798.

25. Aadam AA, Wani S, Amick A, et al. A randomized controlled cross-over trial and cost analysis comparing endoscopic ultrasound fine needle aspiration and fine needle biopsy. Endosc Int Open 2016;4:E497-E505.

26. Kamata K, Kitano M, Yasukawa S, et al. Histologic diagnosis of pancreatic masses using 25-gauge endoscopic ultrasound needles with and without a core trap: a multicenter randomized trial. Endoscopy 2016;48:632-638.

27. Alatawi A, Beuvon F, Grabar S, et al. Comparison of $22 \mathrm{G}$ reverse-beveled versus standard needle for endoscopic ultrasound-guided sampling of solid pancreatic lesions. United European Gastroenterol J 2015;3:343352.
28. Wang J, Zhao S, Chen Y, Jia R, Zhang X. Endoscopic ultrasound guided fine needle aspiration versus endoscopic ultrasound guided fine needle biopsy in sampling pancreatic masses: a meta-analysis. Medicine (Baltimore) 2017;96:e7452.

29. Polkowski M, Jenssen C, Kaye P, et al. Technical aspects of endoscopic ultrasound (EUS)-guided sampling in gastroenterology: European Society of Gastrointestinal Endoscopy (ESGE) technical guideline - March 2017. Endoscopy 2017;49:989-1006.

30. El Hajj II, Wu H, Reuss S, et al. Prospective assessment of the performance of a new fine needle biopsy device for EUS-guided sampling of solid lesions. Clin Endosc 2018;51:576-583.

31. Kwon CI. Will new instruments for endoscopic ultrasound-guided tissue acquisition make us happy? Clin Endosc 2018;51:510-512.

32. Wallace MB, Kennedy T, Durkalski V, et al. Randomized controlled trial of EUS-guided fine needle aspiration techniques for the detection of malignant lymphadenopathy. Gastrointest Endosc 2001;54:441-447.

33. Attam R, Arain MA, Bloechl SJ, et al. "Wet suction technique (WEST)": a novel way to enhance the quality of EUS-FNA aspirate. Results of a prospective, single-blind, randomized, controlled trial using a 22-gauge needle for EUS-FNA of solid lesions. Gastrointest Endosc 2015;81:14011407.

34. Kudo T, Kawakami H, Hayashi T, et al. High and low negative pressure suction techniques in EUS-guided fine-needle tissue acquisition by using 25-gauge needles: a multicenter, prospective, randomized, controlled trial. Gastrointest Endosc 2014;80:1030-1037.e1.

35. Bang JY, Hebert-Magee S, Navaneethan U, Hasan MK, Hawes R, Varadarajulu S. Randomized trial comparing the Franseen and Fork-tip needles for EUS-guided fine-needle biopsy sampling of solid pancreatic mass lesions. Gastrointest Endosc 2018;87:1432-1438.

36. Wani S, Early D, Kunkel J, et al. Diagnostic yield of malignancy during EUS-guided FNA of solid lesions with and without a stylet: a prospective, single blind, randomized, controlled trial. Gastrointest Endosc 2012;76:328-335.

37. Kim JH, Park SW, Kim MK, et al. Meta-analysis for cyto-pathological outcomes in endoscopic ultrasonography-guided fine-needle aspiration with and without the stylet. Dig Dis Sci 2016;61:2175-2184.

38. Abe Y, Kawakami H, Oba K, et al. Effect of a stylet on a histological specimen in EUS-guided fine-needle tissue acquisition by using 22-gauge needles: a multicenter, prospective, randomized, controlled trial. Gastrointest Endosc 2015;82:837-844.el.

39. Park SW, Chung MJ, Lee SH, et al. Prospective study for comparison of endoscopic ultrasound-guided tissue acquisition using 25- and 22-gauge core biopsy needles in solid pancreatic masses. PLoS One 2016;11:e0154401.

40. Eisen GM, Dominitz JA, Faigel DO, et al. Guidelines for credentialing and granting privileges for endoscopic ultrasound. Gastrointest Endosc 2001;54:811-814.

41. Shahidi N, Ou G, Lam E, Enns R, Telford J. When trainees reach competency in performing endoscopic ultrasound: a systematic review. Endosc Int Open 2017;5:E239-E243.

42. Wani S, Keswani R, Hall M, et al. A prospective multicenter study evaluating learning curves and competence in endoscopic ultrasound and endoscopic retrograde cholangiopancreatography among advanced endoscopy trainees: the rapid assessment of trainee endoscopy skills study. Clin Gastroenterol Hepatol 2017;15:1758-1767.e11.

43. Wani S, Hall M, Keswani RN, et al. Variation in aptitude of trainees in endoscopic ultrasonography, based on cumulative sum analysis. Clin Gastroenterol Hepatol 2015;13:1318-1325.e2.

44. Wani S, Coté GA, Keswani R, et al. Learning curves for EUS by using cumulative sum analysis: implications for American Society for Gastrointestinal Endoscopy recommendations for training. Gastrointest Endosc 2013;77:558-565.

45. Wani S, Mullady D, Early DS, et al. The clinical impact of immediate on-site cytopathology evaluation during endoscopic ultrasound-guided fine needle aspiration of pancreatic masses: a prospective multicenter 
randomized controlled trial. Am J Gastroenterol 2015;110:1429-1439.

46. Rodrigues-Pinto E, Jalaj S, Grimm IS, Baron TH. Impact of EUS-guided fine-needle biopsy sampling with a new core needle on the need for onsite cytopathologic assessment: a preliminary study. Gastrointest Endosc 2016;84:1040-1046

47. Keswani RN, Krishnan K, Wani S, Keefer L, Komanduri S. Addition of endoscopic ultrasound (EUS)-guided fine needle aspiration and on-site cytology to EUS-guided fine needle biopsy increases procedure time but not diagnostic accuracy. Clin Endosc 2014;47:242-247.

48. Schmidt RL, Walker BS, Howard K, Layfield LJ, Adler DG. Rapid onsite evaluation reduces needle passes in endoscopic ultrasound-guided fine-needle aspiration for solid pancreatic lesions: a risk-benefit analysis. Dig Dis Sci 2013;58:3280-3286.

49. Wani S, Muthusamy VR, Komanduri S. EUS-guided tissue acquisition: an evidence-based approach (with videos). Gastrointest Endosc 2014;80:939-959.e7.

50. Wani S, Shah RJ. EUS-guided tissue acquisition: do we need to shoot for a "core" to score? Gastrointest Endosc 2016;84:1047-1049.

51. Lee KH, Kim EY, Cho J, et al. Risk factors associated with adverse events during endoscopic ultrasound-guided tissue sampling. PLoS One 2017;12:e189347.

52. Hamada T, Yasunaga H, Nakai Y, et al. Severe bleeding and perforation are rare complications of endoscopic ultrasound-guided fine needle aspiration for pancreatic masses: an analysis of 3,090 patients from 212 hospitals. Gut Liver 2014;8:215-218.

53. Wang KX, Ben QW, Jin ZD, et al. Assessment of morbidity and mortality associated with EUS-guided FNA: a systematic review. Gastrointest Endosc 2011;73:283-290.

54. Yang Y, Li L, Qu C, Liang S, Zeng B, Luo Z. Endoscopic ultrasound-guided fine needle core biopsy for the diagnosis of pancreatic malignant lesions: a systematic review and meta-analysis. Sci Rep 2016;6:22978.

55. Guan YF, Li GR, Wang RJ, et al. Application of next-generation sequencing in clinical oncology to advance personalized treatment of cancer. Chin J Cancer 2012;31:463-470.

56. Park JK, Lee JH, Noh DH, et al. Factors of endoscopic ultrasound-guided tissue acquisition for successful next-generation sequencing in pancreatic ductal adenocarcinoma. Gut Liver 2019 Oct 8 [Epub]. https:// doi/org/10.5009/gnl19011.

57. Gleeson FC, Kipp BR, Voss JS, et al. Endoscopic ultrasound fine-needle aspiration cytology mutation profiling using targeted next-generation sequencing: personalized care for rectal cancer. Am J Clin Pathol 2015;143:879-888.

58. Bellevicine C, Vita GD, Malapelle U, Troncone G. Applications and limitations of oncogene mutation testing in clinical cytopathology. Semin Diagn Pathol 2013;30:284-297.

59. Navina S, McGrath K, Chennat J, et al. Adequacy assessment of endoscopic ultrasound-guided, fine-needle aspirations of pancreatic masses for theranostic studies: optimization of current practices is warranted. Arch Pathol Lab Med 2014;138:923-928.

60. Roy-Chowdhuri S, Chen H, Singh RR, et al. Concurrent fine needle as- pirations and core needle biopsies: a comparative study of substrates for next-generation sequencing in solid organ malignancies. Mod Pathol 2017;30:499-508.

61. Wei S, Lieberman D, Morrissette JJ, Baloch ZW, Roth DB, McGrath C. Using "residual" FNA rinse and body fluid specimens for next-generation sequencing: an institutional experience. Cancer Cytopathol 2016;124:324-329.

62. Rekhtman N, Roy-Chowdhuri S. Cytology secimens: a goldmine for molecular testing. Arch Pathol Lab Med 2016;140:1189-1190.

63. Rodriguez SA, Impey SD, Pelz C, et al. RNA sequencing distinguishes benign from malignant pancreatic lesions sampled by EUS-guided FNA. Gastrointest Endosc 2016;84:252-258.

64. Bournet B, Gayral M, Torrisani J, Selves J, Cordelier P, Buscail L. Role of endoscopic ultrasound in the molecular diagnosis of pancreatic cancer. World J Gastroenterol 2014;20:10758-10768.

65. Gayral M, Jo S, Hanoun N, et al. MicroRNAs as emerging biomarkers and therapeutic targets for pancreatic cancer. World J Gastroenterol 2014;20:11199-11209.

66. Berry W, Algar E, Kumar B, et al. Endoscopic ultrasound-guided fine-needle aspirate-derived preclinical pancreatic cancer models reveal panitumumab sensitivity in KRAS wild-type tumors. Int J Cancer 2017;140:2331-2343.

67. Ribeiro A, Peng J, Casas C, Fan YS. Endoscopic ultrasound guided fine needle aspiration with fluorescence in situ hybridization analysis in 104 patients with pancreatic mass. J Gastroenterol Hepatol 2014;29:16541658.

68. Boj SF, Hwang CI, Baker LA, Engle DD, Tuveson DA, Clevers H. Model organoids provide new research opportunities for ductal pancreatic cancer. Mol Cell Oncol 2016;3:e1014757.

69. Boj SF, Hwang CI, Baker LA, et al. Organoid models of human and mouse ductal pancreatic cancer. Cell 2015;160:324-338.

70. Huang L, Holtzinger A, Jagan I, et al. Ductal pancreatic cancer modeling and drug screening using human pluripotent stem cell- and patient-derived tumor organoids. Nat Med 2015;21:1364-1371.

71. Buscaglia JM, Bucobo JC, Tiriac H, et al. Successful creation of pancreatic cancer organoids by means of EUS-guided fine-needle biopsy (EUSFNB) for personalized cancer treatment. Gastrointest Endosc 2017;85(5 Suppl):AB50-AB51.

72. Tan S, Yeo T, Sukhatme SA, Kong SL, Lim WT, Lim CT. Personalized treatment through detection and monitoring of genetic aberrations in single circulating tumor cells. Adv Exp Med Biol 2017;994:255-273.

73. Palmirotta R, Lovero D, Silvestris E, et al. Next-generation sequencing (NGS) analysis on single circulating tumor cells (CTCs) with no need of whole-genome amplification (WGA). Cancer Genomics Proteomics 2017;14:173-179.

74. Ankeny JS, Court CM, Hou S, et al. Circulating tumour cells as a biomarker for diagnosis and staging in pancreatic cancer. Br J Cancer 2016;114:1367-1375.

75. Catenacci DV, Chapman CG, Xu P, et al. Acquisition of portal venous circulating tumor cells from patients with pancreaticobiliary cancers by endoscopic ultrasound. Gastroenterology 2015;149:1794-1803.e4. 